\title{
Protective effects of fustin, a flavonoid from Rhus verniciflua Stokes, on 6-hydroxydopamine-induced neuronal cell death
}

\author{
Byung Chul Park', Yong Soo Lee ${ }^{2}$, \\ Hee-Juhn Park ${ }^{3}$, Mi-Kyoung Kwak', \\ Bong Kyu Yoo', Joo Young $\mathrm{Kim}^{4}$ \\ and Jung-Ae $\mathrm{Kim}^{1,5}$ \\ ${ }^{1}$ College of Pharmacy, Yeungnam University \\ Gyeongsan 712-749, Korea \\ ${ }^{2}$ College of Pharmacy, Duksung Women's University \\ Seoul 132-714, Korea \\ ${ }^{3}$ Division of Applied Plant Sciences \\ Sangji University \\ Wonju 220-702, Korea \\ ${ }^{4}$ Department of Anatomy \\ College of Medicine, Yeungnam University \\ Daegu 705-717, Korea \\ ${ }^{5}$ Corresponding author: Tel, 82-53-810-2816; \\ Fax, 82-53-810-4654; E-mail, jakim@yu.ac.kr
}

\section{Accepted 15 March 2007}

Abbreviations: 6-OHDA, 6-hydroxydopamine; BAPTA/AM, bis-(0aminophenoxy)-ethane- $N, N, N, N$-tetraacetic acid/acetoxymethyl ester; Fura-2/AM, 1-(2,5-carboxyoxazol-2-yl-6-aminobenzfuran-5-oxyl)-2(2'-amino-methylphenoxy)-ethane- $N, N, N, N$-tetraacetoxylmethyl ester; NAC, $\mathrm{N}$-acetylcysteine; $\mathrm{PI}$, propidium iodide; ROS, reactive oxygen species

\begin{abstract}
6-Hydroxydopamine (6-OHDA) is a neurotoxin and is commonly used to generate experimental models of Parkinson's disease (PD). In this study, we investigated the signaling molecules involved in the 6OHDA-induced cell death using a neuronal catecholaminergic cell line (SK-N-SH cells), and the protective effect of fustin, a flavonoid from Rhus verniciflua Stokes, on 6-OHDA-induced neuronal death. 6-OHDA significantly increased levels of reac tive oxygen species (ROS), intracellular $\mathrm{Ca}^{2+}\left(\left[\mathrm{Ca}^{2+}\right]_{i}\right)$, and p38 phosphorylation. In addition, this ROS increase by 6-OHDA was reduced by pretreatment with $\mathrm{N}$-acetylcysteine (NAC), a free radical scavenger, but not by bis-(o-aminophenoxy)- ethane- $N, N, N, N$ tetraacetic acid (BAPTA), a $\mathrm{Ca}^{2+}$ chelator. However, the $\left[\mathrm{Ca}^{2+}\right]_{i}$ increase induced by 6-OHDA was suppressed by NAC. Moreover, pretreatment with NAC or BAPTA significantly prevented the 6-OHDA-
\end{abstract}

induced increases in p38 phosphorylation, Bax/ Bcl-2 ratio, and caspase-3 activity. Although 6OHDA-increased phosphorylation of p38 was prevented by NAC or BAPTA, inhibition of p38 by SB203580 did not suppress ROS, Bax/Bcl-2 ratio, or caspase-3 activity increases, and only partially prevented 6-OHDA-induced cell death, thus demon strating that p38 activation is a component of a signaling pathway leading to the initiation of 6-OHDA-induced cell death, which acts in parallel with an $\mathrm{ROS}-\mathrm{Ca}^{2+}-\mathrm{Bcl}-2-$ caspase-3 pathway. More over, fustin not only suppressed 6-OHDA-induced cell death in a concentration-dependent manner but also blocked 6-OHDA-induced increases in ROS, $\left[\mathrm{Ca}^{2+}\right]_{\mathrm{i}}, \mathrm{Bax} / \mathrm{Bcl}-2$ ratio, caspase-3 activity, and p38 phosphorylation. These results suggest that fustin exerts neuroprotection against 6-OHDA-induced cell death.

Keywords: calcium; caspase-3; cell death; oxidopamine; p38 mitogen-activated protein kinases; Parkinson disease; reactive oxygen species

\section{Introduction}

Parkinson's disease (PD) is a widespread neurodegenerative disorder that is characterized by the progressive degeneration of dopaminergic neurons in the substantia nigra. Although the etiology of PD remains unknown, oxidative stress induced by the autooxidation of dopamine or by the activation of monoamine oxidase has been proposed as a mechanistic possibility (Danielczyk et al., 1988; Cohen et al., 1997; Floor and Wetzel, 1998; Lotharius and Malley, 2000; Bharath et al., 2002). In addition, mitochondrial dysfunction has also been shown to be involved in the pathogenesis of $P D$ (Hattori et al., 1991; Sherer et al., 2002). However, the mechanism underlying neuronal degeneration in PD is unknown. Moreover, it is evident that an understanding of the molecular signaling involved in the degeneration of dopaminergic neurons is likely to aid the search for suitable therapeutic agents.

Since 6-hydroxydopamine (6-OHDA) is known to cause selective catecholaminergic cell death and to be present at elevated concentrations in the brain and urine of Parkinsonian patients (Curtius et al., 1974; Andrew et al., 1993), 6-OHDA-induced dopa- 
minergic neuron cell death has been widely used to create toxin-induced in vitro and in vivo models of PD (Sauer and Oertel, 1994; Przedborski et al., 1995; Beal, 2001). Moreover, in vitro models have also been found to be useful in molecular signaling studies and for testing new pharmacologic agents.

Although the precise mechanism of 6-OHDAinduced cytotoxicity has not yet been clarified, oxidative stress has attracted much attention as an important mediator of 6-OHDA-induced cytotoxicity in vivo (Kumar et al., 1995) and in vitro (Choi et al., 1999; Shimizu et al., 2002). Moreover, the generation of ROS and oxidized products, such as, $p$-quinone and aminochrome, has been reported during the nonenzymatic autooxidation of 6-OHDA (Soto-Otero et al., 2000; Seitz et al., 2005). In addition, it has been reported that 6-OHDA itself (rather than its oxidation products) is responsible for neurotoxicity by inhibiting respiratory chain enzymes (Glinka and Youdim, 1995).

Neuronal damage resulting from oxidative stress has been related to the activation of apoptotic pathways by signaling molecule regulation (Xia et al., 1995; Chun et al., 2001). Stress-activated protein kinases, such as, JNK and p38 are known potent effectors of neuronal apoptosis in response to various stimuli (Mielke and Herdegen, 2000). In fact, the active forms of JNK and p38 have been found in the PD brain post- mortem (Ferrer et al., 2001) as well as in experimental animals (Saporito et al., 1999, 2000) and in culture models of PD (Cassarino et al., 2000; Choi et al., 2004). Furthermore, it has been reported that the 6-OHDA-induced phosphorylation of p38 is linked to the activations of caspase- 8 and -9 , and thus, to apoptosis.

In addition to oxidative stress, 6-OHDA induces $\mathrm{Ca}^{2+}$ release from mitochondria (Reichman et al., 1994). More recently, it was shown that an increase in cytosolic $\mathrm{Ca}^{2+}$ concentrations leads to a mitochondrial calcium overload (Lee et al., 2002), and that the inhibition of mitochondrial calcium uptake has been found to be antiapoptotic in several cell death models (Reynolds, 1999; Bae et al., 2003; Jambrina et al., 2003). However, the relationship between ROS and $\left[\mathrm{Ca}^{2+}\right]_{i}$ in the 6-OHDA-induced cell death signaling pathway has not been clarified.

Fustin is an active component of the heartwood of Rhus verniciflua. Unlike the stem bark, which contains allergenic urshinols, the heartwood does not have an allergenic effect and has been traditionally used as a food additive and herbal medicine to treat rheumatoid arthritis. Recently, the methanol extract of Rhus verniciflua heartwood, which contains fustin, showed anti-rheumatoid arthritis and antimutagenic activities which were found to be mediated via antioxidant activity (Choi et al., 2003; Park et al., 2004).
In the present study, we investigated the signaling pathway involved in 6-OHDA-induced cell death, and the protective effect of fustin on 6-OHDA-induced neuronal death.

\section{Materials and Methods}

\section{Cell line and cell culture}

The SK-N-SH human neuroblastoma cell line was purchased from the American Type Culture Collection (Rockville, MA) and grown at $37^{\circ} \mathrm{C}$ in a humidified incubator under $5 \% \mathrm{CO}_{2} / 95 \%$ air in Eagle's MEM supplemented with $10 \%$ FBS, $1 \mathrm{mM}$ sodium pyruvate, $200 \mathrm{IU} / \mathrm{ml}$ penicillin and $200 \mu \mathrm{g} / \mathrm{ml}$ streptomycin. The culture medium was replaced every other day. Cells were cultured in 96-well plates for cell viability assays and in $100 \mathrm{~mm}$-diameter dishes for GSH content and enzyme activity assays.

\section{6-OHDA treatment}

6-OHDA was dissolved in MEM including $0.1 \%$ ascorbic acid. Other inhibitors were co-treated or pretreated $4 \mathrm{~h}$ or $30 \mathrm{~min}$ prior to $6-$ OHDA $(125 \mu \mathrm{M})$ treatment.

\section{MTT assay}

Cell viabilities were measured using 3-[4,5-dimethylthiazol-2-yl]-2,5-diphenyltetrazolium bromide (MTT) assays. Cells were plated at a density of $2 \times 10^{4}$ cells/well in a 96-well plate and treated with 6-OHDA. Then, $10 \mu$ of $5 \mathrm{mg} / \mathrm{ml}$ of MTT solution was added to the culture medium and incubated for $4 \mathrm{~h}$ at $37^{\circ} \mathrm{C}$.

\section{Determination of apoptosis}

Cells were plated at a density of $1 \times 10^{5}$ cells per well in 6-well plates and treated with 6-OHDA for up to $24 \mathrm{~h}$. For flow cytometry analysis, cells were collected and washed twice with PBS (pH 7.4). After fixing in $80 \%$ ethanol for $30 \mathrm{~min}$, cells were washed twice, and resuspended in PBS (pH 7.4) containing $50 \mu \mathrm{g} / \mathrm{ml} \mathrm{PI}$ and $25 \mu \mathrm{g} / \mathrm{ml}$ ribonuclease A for DNA staining. They were then analyzed using a FACS Calibur flow cytometer (Becton Dickson, CA). At least 20,000 events were evaluated. All histograms were analyzed using Cell Quest (Becton Dickson, CA) to determine percentage of hypodiploid nuclei as an indicator of apoptosis (Hockenbery et al., 1990).

\section{Western blot analysis}

Cells were lysed in freshly prepared extraction buffer [10 mM Tris- $\mathrm{HCl}(\mathrm{pH} 7.6), 0.1 \%$ Nonidet P-40, 150 $\mathrm{mM} \mathrm{NaCl}, 10 \mathrm{mM}$ EDTA, $1 \mathrm{mM}$ phenylmethylsulfonyl 
fluoride, $2 \mu \mathrm{g} / \mathrm{ml}$ leupeptin, $2 \mu \mathrm{g} / \mathrm{ml}$ aprotinin, and 1 $\mu \mathrm{g} / \mathrm{ml}$ pepstatin (Sigma-Aldrich, MO)] for $30 \mathrm{~min}$ at $4{ }^{\circ} \mathrm{C}$. Protein detection was performed using Bradford reagent (Bio-Rad, CA). Lysates were centrifuged at $20,000 \mathrm{~g}$ for $10 \mathrm{~min}$ at $4^{\circ} \mathrm{C}$, and supernatant proteins were separated by $10 \%$ SDS-PAGE and transferred to Hybond ECL nitrocellulose membranes (Amersham Life Science, Buckinghamshire, England). Membranes were blocked with $5 \%$ skimmed milk in Tween-20 containing Tris buffered saline (TTBS) $(20$ $\mathrm{mM}$ Tris- $\mathrm{HCl}$ ( $\mathrm{pH} 7.6), 150 \mathrm{mM} \mathrm{NaCl}, 0.05 \%$ Tween20) and then incubated with primary anti-human $\mathrm{Bcl}-2$, Bax, p38, pp38, caspase-3 (cleaved form specific), and actin antibodies in TTBS containing $3 \%$ skimmed milk. The antibodies were obtained from Cell Signaling Technology (Beverly, MA) except for Bcl-2 and Bax from Santa Cruz Biotechnology (Santa Cruz, CA). After incubation with HRPconjugated anti-lgG antibody (Santa Cruz Biotechnology, CA), immunodetected proteins were visualized using an enhanced chemiluminescence assay kit (Amersham Biosciences, Buckinghamshire, England). Protein band densities were measured using an Image Analyzing System (UVP, Upland, CA).

\section{ROS measurements (Nitroblue tetrazolium reduction assay)}

Intracellular superoxide generation was measured by following the conversion of nitroblue tetrazolium (NBT) to formazan. NBT was added to the culture medium to a final concentration of $1 \mathrm{mg} / \mathrm{ml}$. After 6-OHDA treatment, cells were lysed and formazan was dissolved with $2 \mathrm{M} \mathrm{KOH}$ and 1.4 volumes of DMSO. Absorbances were read at $654 \mathrm{~nm}$.

\section{Measurements of $\left[\mathrm{Ca}^{2+}\right]_{i}$ Levels}

Intracellular free $\mathrm{Ca}^{2+}$ concentrations were determined using the fluorescent $\mathrm{Ca}^{2+}$ indicator Fura-2. Briefly, SK-N-SH cells $\left(4.5 \times 10^{5}\right.$ cells/well $)$ were cultured in a 6-well plate. The cells were then loaded with Fura-2 acetoxymethylester (Fura-2/AM) to a final concentration of $3 \mu \mathrm{M}$ in complete medium and incubated at $37^{\circ} \mathrm{C}$ for 50 min with shaking. After the loading, cells were washed twice with Locke's solution (154 mM NaCl, $5.6 \mathrm{mM} \mathrm{KCl}, 1.2 \mathrm{mM} \mathrm{MgCl}_{2}, 2.2$ $\mathrm{mM} \mathrm{CaCl}, 5 \mathrm{mM}$ HEPES and $10 \mathrm{mM}$ glucose, at $\mathrm{pH}$ $7.4)$ to remove unloaded Fura-2. Sulfinpyrazone was added to both the loading medium and washing solution to a final concentration of $250 \mu \mathrm{M}$ to prevent dye leakage (Di Vergilio et al., 1988). Intracellular $\mathrm{Ca}^{2+}$ levels were determined from fluorescence intensities measured using a FLUOstar OPTIMA microplate reader (BMG LABTECH, Germany). The Fura-2-loaded culture plate was placed into a thermostatically controlled plate holder at $37^{\circ} \mathrm{C}$ with shaking. Fluorescence emission at $510 \mathrm{~nm}$ was monitored with the excitation wavelength cycling between 340 and $380 \mathrm{~nm}$. The $\left[\mathrm{Ca}^{2+}\right]_{i}$ was expressed as 380:340 $\mathrm{nm}$ fluorescence ratios.

\section{Measurement of caspase-3 activity}

Caspase-3 activity was measured by using an ApoAlert caspase colorimetric assay kit (BD Biosciences, San Jose, CA). Briefly, cell lysates were mixed with DTT (10 mM)-rich reaction buffer containing 50 $\mu \mathrm{M}$ DEVD-pNA, a caspase-3 substrate, and incubated for $1 \mathrm{~h}$ at $37^{\circ} \mathrm{C}$. Enzyme-catalyzed release of pNA was monitored using a microplate reader at 405 $\mathrm{nm}$.

\section{Data analysis}

The data are expressed as means \pm SEM and analyzed using one-way ANOVA and the StudentNewman-Keul's test for individual comparisons. $P$ values of $<0.05$ were considered statistically significant.

\section{Results}

\section{Protective effect of fustin on 6-OHDA-induced cell death}

To determine whether fustin has a protective action in 6-OHDA-induced apoptotic SK-N-SH cell death, we first performed an MTT cell viability assay, which showed that fustin suppressed 6-OHDA-induced cell death in a concentration-dependent manner (Figure 1A). Treatment with fustin alone up to $200 \mu \mathrm{M}$ did not affect viability of the cells. According to flow cytometry measurements, 6-OHDA-induced apoptosis, as determined by $\mathrm{PI}$ staining for hypodiploid DNA content, was significantly prevented by fustin pretreatment (Figure 1B).

Since it has been reported that many molecular species are associated with 6-OHDA-induced cell death, e.g., reactive oxygen species, $\left[\mathrm{Ca}^{2+}\right]_{\mathrm{i}}$, and MAPKs, we examined which of these signaling molecules are involved in the protective effect of fustin. Thus, we compared the effects of specific ROS, intracellular $\mathrm{Ca}^{2+}$ and MAPKs inhibitors on the protective effect of fustin. PD98059 $(10 \mu \mathrm{M})$, an ERK inhibitor, had no effect on 6-OHDA-induced cell death. In contrast, 6-OHDA-induced cell death was prevented by the pretreating cells with the following; $\mathrm{N}$-acetylcysteine (NAC) $(10 \mathrm{mM}$; a free radical scavenger), BAPTA (2 $\mu \mathrm{M}$; an intracellular $\mathrm{Ca}^{2+}$ chelator), and SB203580 (10 $\mu \mathrm{M}$; a p38 inhibitor). Of these NAC had the greatest protective effect on 6-OHDA-treated cells, and SB203580 least effect 
A

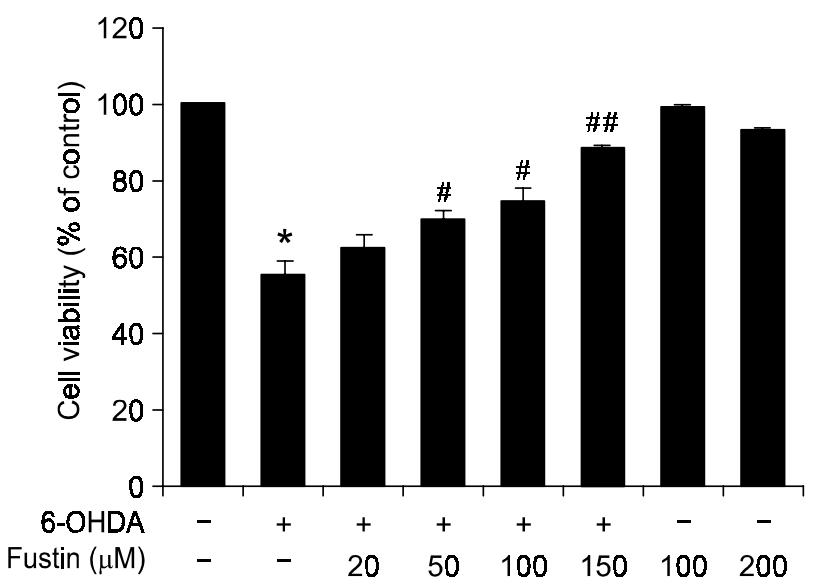

B
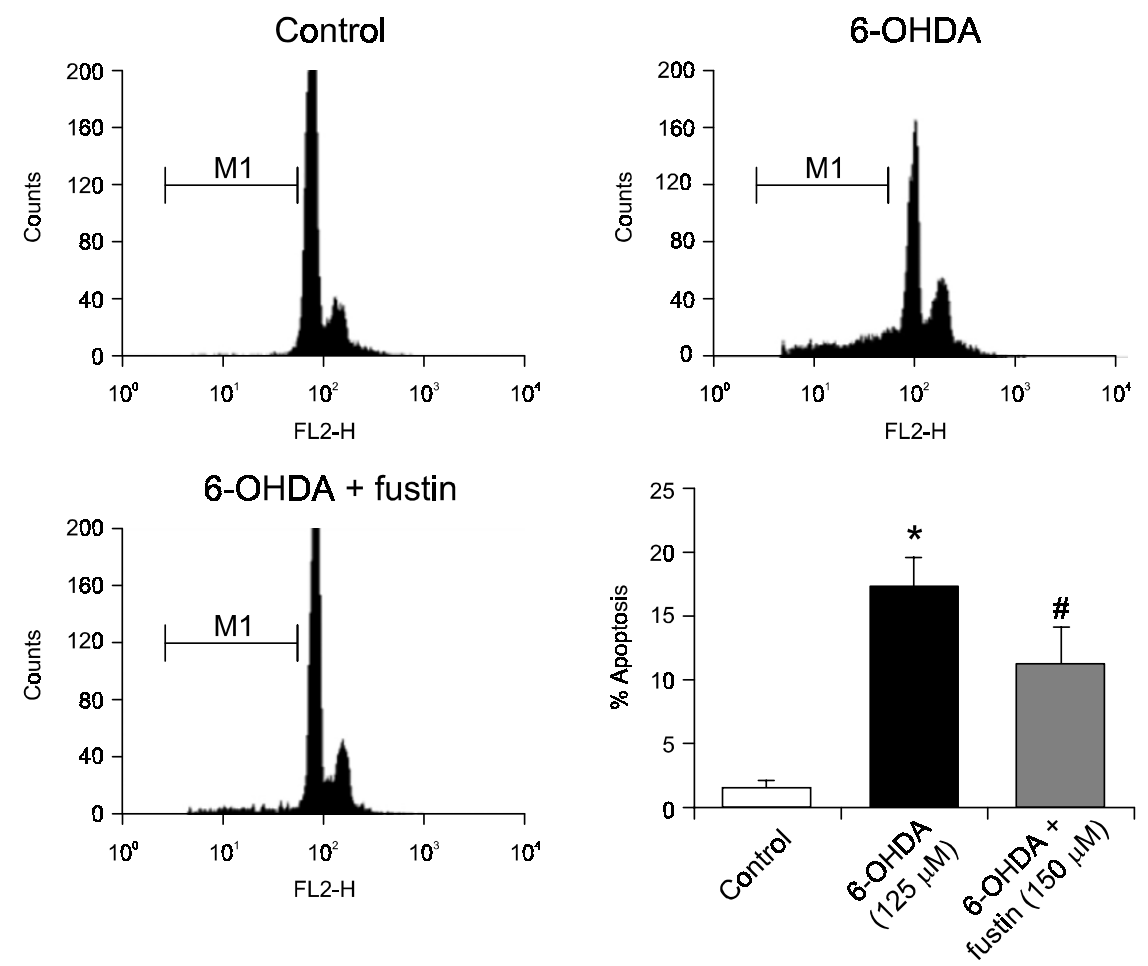

Figure 1. Protective effect of fustin on the 6-OHDA-induced cell death. (A) SK-N-SH cells were pretreated with fustin 30 min prior to 6-OHDA $(125 \mu \mathrm{M})$ treatment for $48 \mathrm{~h}$, and cell viability was measured using MTT assay. (B) Numbers of apoptotic cells were measured by flow cytometry after PI staining. Cells were pretreated with fustin for 30 min prior to 6-OHDA treatment for $24 \mathrm{~h}$. The data points shown represent the mean values of three independent experiments and bars indicate SEMs. ${ }^{*} P<0.05 \mathrm{com}$ pared to the untreated control, ${ }^{\#} P$ $<0.05$ compared to $6-\mathrm{OHDA}$ alone.

\section{(Figure 2).}

\section{The effects of fustin on 6-OHDA-induced ROS and $\left[\mathrm{Ca}^{2+}\right]$ increases}

The similarities observed between the degree of protection against 6-OHDA-induced cell death by fustin and co-treatment with NAC or BAPTA indicate that fustin acts via $\mathrm{ROS}$ and $\left[\mathrm{Ca}^{2+}\right]_{i}$ signals. Thus, we examined whether fustin inhibits the ROS and $\left[\mathrm{Ca}^{2+}\right]_{i}$ signals associated with 6-OHDA-induced cell death.
6-OHDA was found to significantly increase ROS levels (Figure $3 \mathrm{~A}$ ), and this was significantly suppressed by fustin $(150 \mu \mathrm{M})$ but not by SB203580 $(10 \mu \mathrm{M})$ or BAPTA $(2 \mu \mathrm{M})$ (Figure $3 \mathrm{~B})$. In addition, the degree of suppression exerted by fustin against ROS increase by 6-OHDA was nearly similar to the effect of NAC $(10 \mathrm{mM})$.

As a next step, we assessed the effects of fustin on 6-OHDA-induced $\left[\mathrm{Ca}^{2+}\right]$. 6-OHDA was found to significantly increase $\left[\mathrm{Ca}^{2+}\right]_{i}$ in a time-dependent 
manner (Figure 4A), and this was suppressed by pretreatment with fustin or NAC (Figure 4B). Furthermore, pretreatment of fustin almost completely

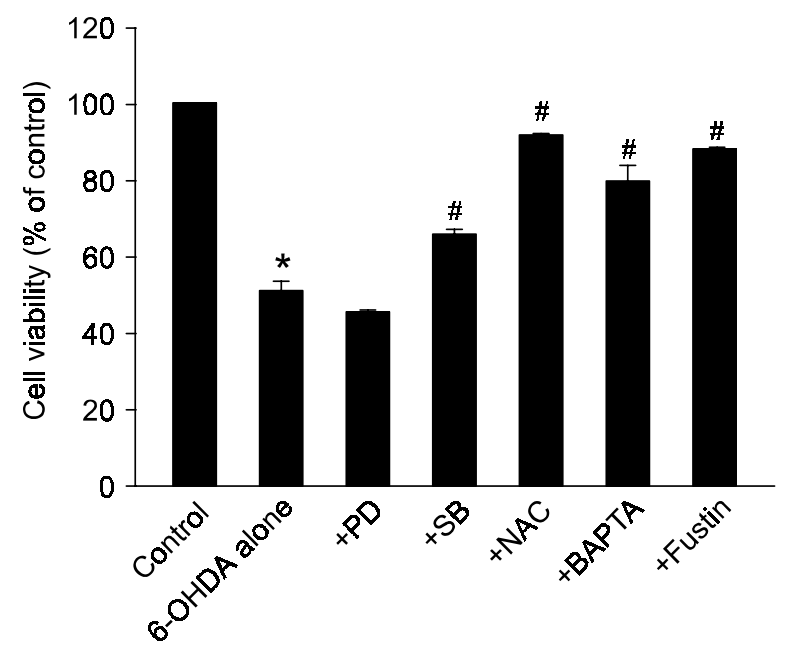

Figure 2. Intracellular signals involved in 6-OHDA toxicity and protective action of fustin: p38, ROS, and $\left[\mathrm{Ca}^{2+}\right]$. Cells were treated with 6-OHDA after being pretreated with PD98059 $(10 \mu \mathrm{M})$, SB203580 (10 $\mu \mathrm{M}), \mathrm{NAC}(10 \mathrm{mM})$ or fustin $(150 \mu \mathrm{M})$ for $30 \mathrm{~min}$, or BAPTA $(2 \mu \mathrm{M})$ for $4 \mathrm{~h}$. Data points represent the mean values of three independent experiments performed in triplicate. Bars indicate SEMs. ${ }^{*} P<0.05 \mathrm{com}$ pared to the 6-OHDA untreated control. ${ }^{\#} P<0.05$ compared to 6-OHDA-treated group.

A

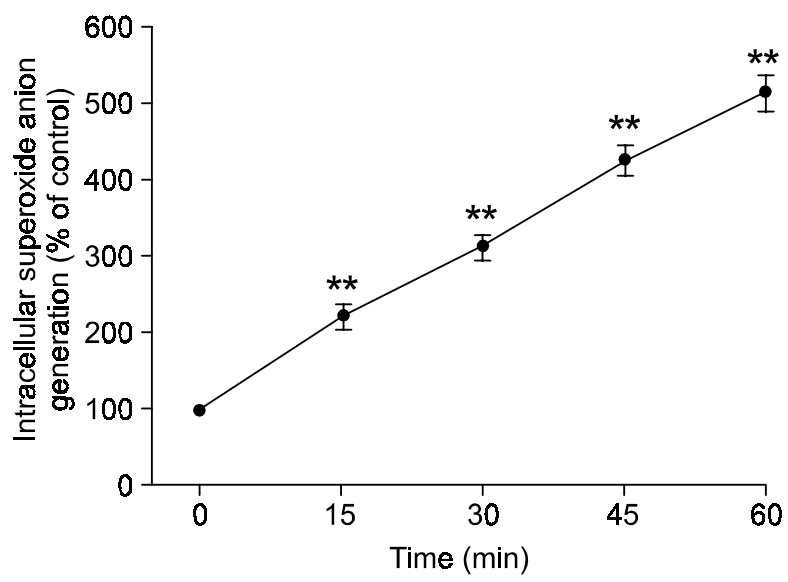

suppressed the $\left[\mathrm{Ca}^{2+}\right]_{\mathrm{i}}$ increase induced by $6-\mathrm{OHDA}$.

\section{Effects of fustin on the 6-OHDA-induced expressions of Bax and Bcl-2}

Of the various upstream signals associated with neuronal degeneration, Bcl-2 family members have been shown to play a role in mediating cell death in response to oxidative stress (Bruce-Keller et al., 1998; Hochman et al., 1998). Indeed, Bax has been specifically shown to be increased in the dopaminergic degeneration associated with PD (Tatton, 2000). In the present study, we found that 6-OHDA down-regulated $\mathrm{Bcl}-2$ (an anti-apoptotic protein), in a time-dependent manner, but did not affect the expression of Bax (a pro-apoptotic protein), thus resulting in $\mathrm{Bax} / \mathrm{Bcl}-2$ ratio increase, in whole cell SK-N-SH lysate (Figure 5A). However, fustin prevented 6OHDA-induced Bax/Bcl-2 ratio increase. Nevertheless, treatment with NAC or BAPTA completely suppressed 6-OHDA-induced increase in Bax/Bcl-2 ratio. However, pretreatment with SB203580 did not block Bax/Bcl-2 ratio increase by $6-$ OHDA (Figure $5 \mathrm{~B}$ ).

\section{The effects of fustin on the 6-OHDA-induced caspase-3 activation}

Since Bcl-2 family members are known to act upstream of caspase activation (Gross et al., 1999; Borner, 2003), and the activation of caspase-3 is
B

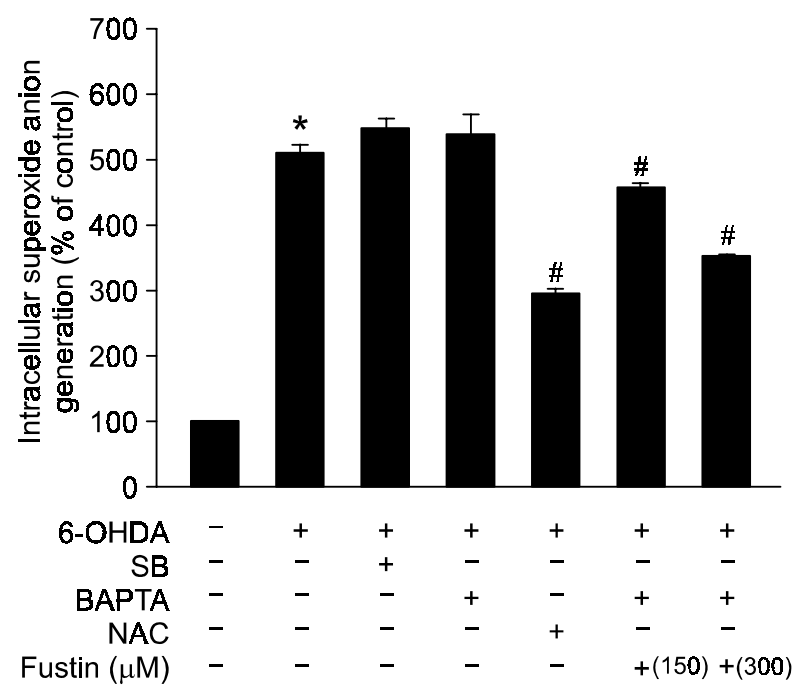

Figure 3. NAC and BAPTA suppress 6-OHDA-induced intracellular ROS. (A) Basal levels of ROS as a function of time after 6-OHDA treatment were measured using the NBT method, and results are expressed as fold increases versus untreated control intensities. (B) Cells were pretreated with SB203580 $(10 \mu \mathrm{M})$, NAC $(10 \mathrm{mM})$ or fustin $(150 \mu \mathrm{M}$ and $300 \mu \mathrm{M})$ for $30 \mathrm{~min}$, or BAPTA $(2 \mu \mathrm{M})$ for $4 \mathrm{~h}$ prior to 6-OHDA treatment for $1 \mathrm{~h}$. Data points represent the mean values of the three independent experiments performed in triplicate. Bars indicate SEMs. ${ }^{*} P<0.05$ compared with the 6 -OHDA untreated control. ${ }^{\#} P<0.05$ compared to treatment with 6-OHDA alone. 
A

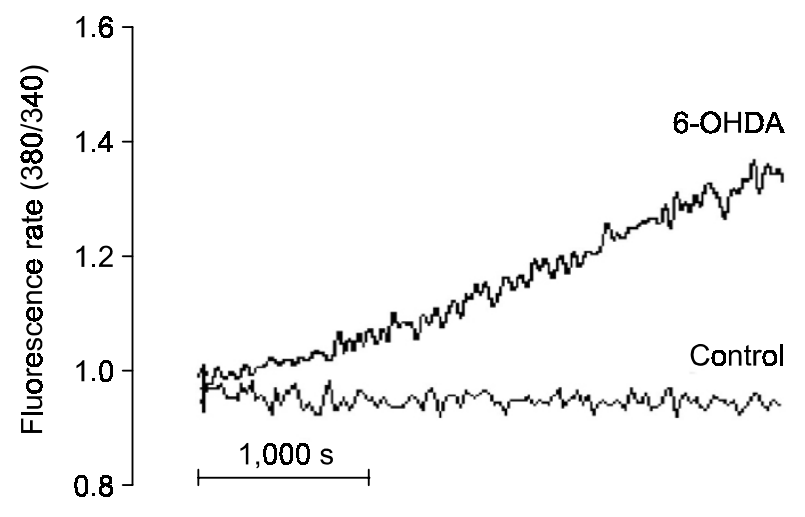

B

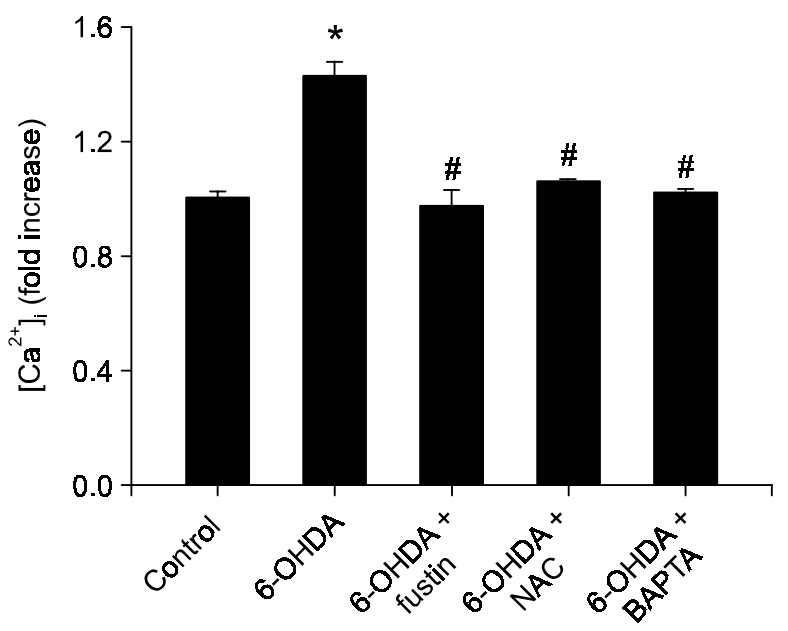

Figure 4. Fustin and NAC block 6-OHDA-induced $\left[\mathrm{Ca}^{2+}\right]_{\mathrm{i}}$ increase. (A) 6-OHDA-induced changes in $\left[\mathrm{Ca}^{2+}\right]_{\mathrm{i}}$ levels are expressed as fold increases versus baseline Fura-2 fluorescence intensities. (B) Changes in $\left[\mathrm{Ca}^{2+}\right]_{i}$ levels are expressed as fold increases versus the control, whereby cells were incubated with 6-OHDA-free medium. Fustin $(150 \mu \mathrm{M})$ and NAC $(1 \mathrm{mM})$ were added 30 min before 6-OHDA. The data points shown represent the mean values of three independent experiments and bars indicating SEMs. ${ }^{*} P<0.05$ versus the control condition whereby cells were incubated with 6-OHDA-free medium. ${ }^{\#} P<0.05$ versus 6 -OHDA treatment alone.

known to play an important role in the formation of apoptotic bodies, we examined the effects of fustin on the 6-OHDA-induced activation of caspase-3. The treatment with 6-OHDA induced cleavage of caspase- 3 into its 17 and $19 \mathrm{kDa}$ active forms at $6 \mathrm{~h}$ and until $12 \mathrm{~h}$ post-treatment (Figure 6A), which corresponded to an increase in caspase- 3 activity (Figure 6B). However, pretreatment with fustin significantly reduced this 6-OHDA-increased caspase-3 activity (Figure 6C). Moreover, pretreatment with NAC or BAPTA also prevented caspase-3 activity increase by $6-$ OHDA. However, pretreatment with SB203580 did not affect the caspase- 3 activity increase induced by $6-$ OHDA.

\section{The effects of fustin on the 6-OHDA-induced phosphorylation of p38}

Although the participation of p38 in dopaminergic cell death is controversial, in Figure 2, SB203580 had some protective effect on 6-OHDA-induced cell death. Therefore, we investigated the effect of fustin on p38 activation. p38 phosphorylation was markedly elevated at $3 \mathrm{~h}$ following 6-OHDA treatment and this was sustained up to $6 \mathrm{~h}$ post-treatment (Figure 7A). Fustin significantly blocked 6-OHDA-induced p38 phosphorylation. Similarly, pretreatment with NAC or BAPTA prevented p38 phosphorylation by 6-OHDA (Figure 7B).

\section{Discussion}

Our present study shows that 6-OHDA-induced cell death is mediated through ROS and $\left[\mathrm{Ca}^{2+}\right]_{i}$ increases of which downstream pathway involves mitochondrial (Bcl-2-caspase-3) as well as non-mitochondrial (p38 activation) signals. More importantly, we found that fustin protected neurons against 6OHDA-induced death by blocking ROS and $\left[\mathrm{Ca}^{2+}\right]_{i}$ increases and the downstream signals, both mitochondrial and non-mitochondrial pathways, by 6-OHDA.

The generation of ROS has been proposed to play an essential role in the pathogenesis of neurodegenerative diseases, including PD (Dauer and Przedborski, 2003; Dawson and Dawson, 2003). In particular, 6-OHDA, one of the most commonly used catecholaminergic neurotoxins, is known to produce ROS (Vroegop et al., 1995; Lotharius et al., 1999) and to potently inhibit mitochondrial electron transport chain complexes I and IV (Ogawa et al., 1994; Glinka et al., 1997). Reduced GSH and its precursor NAC are recognized as highly effective antioxidants, and have been shown to protect against neuronal degeneration in the 6-OHDA-challenged rat striatum (Froissard et al., 1997). The disruption of mitochondrial $\mathrm{Ca}^{2+}$ homeostasis has been suggested to be a major cause of cell damage during conditions of oxidative stress (Richter and Frei, 1988; Kim et al., 1998). In addition, it has been reported that 6-OHDA induces $\mathrm{Ca}^{2+}$ release from mitochondria (Reynolds, 1999; Bae et al., 2003; Jambrina et al., 2003). In the present study, ROS increase by 6-OHDA was not 
A

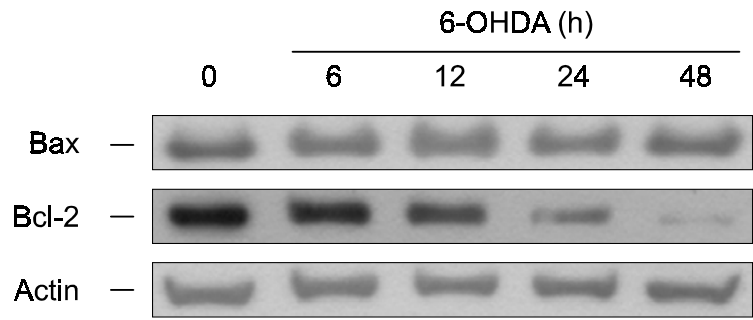

B
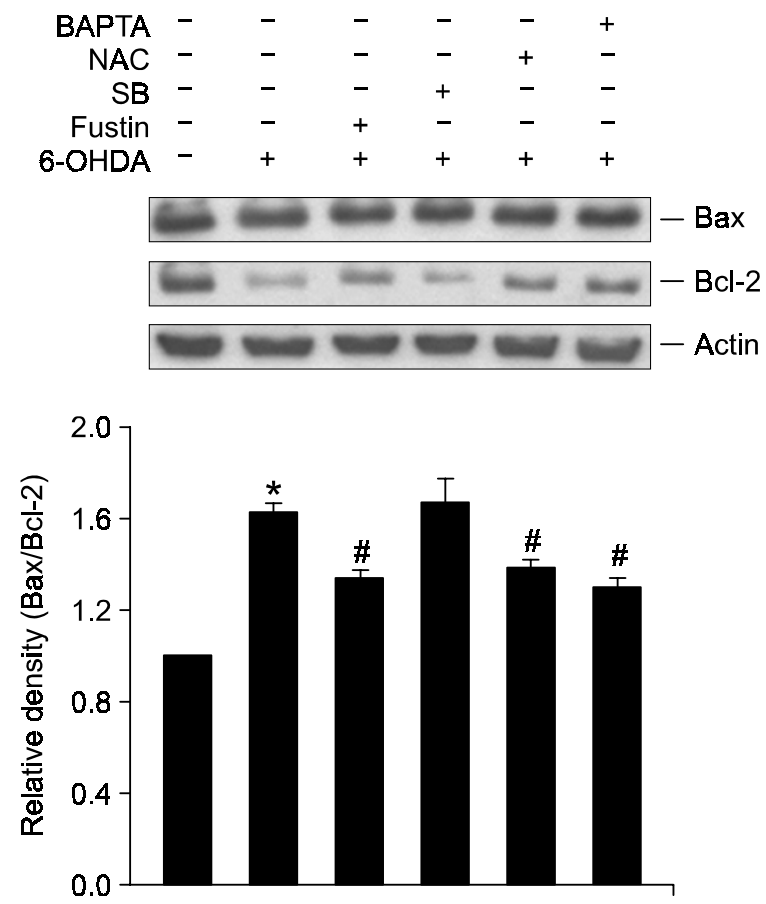

Figure 5. Fustin, NAC and BAPTA prevent 6-OHDA-induced alteration of Bax/Bcl-2 ratio in SK-N-SH cells. Cells were exposed to $125 \mu \mathrm{M}$ of $6-\mathrm{OHDA}$ for $48 \mathrm{~h}$. Fustin $(150 \mu \mathrm{M})$, NAC (1 mM), or SB203580 (10 $\mu \mathrm{M}$ ) were added 30 min prior to $6-\mathrm{OHDA}$ and BAPTA $(2 \mu \mathrm{M})$ was added $4 \mathrm{~h}$ before 6-OHDA. Cells were lysed and equal amounts of protein were immunoblotted using antibodies against Bax and Bcl-2. In the bar graph, data points represent mean values of the relative densities of $\mathrm{Bax}$ and $\mathrm{Bcl}-2$ in three independent experiments and bars indicating SEMs. ${ }^{*} P<0.05$ compared to the untreated control. ${ }^{\sharp} P<0.05$ compared to 6-OHDA treatment alone.

blocked by BAPTA, a $\mathrm{Ca}^{2+}$ chelator, whereas elevation of $\left[\mathrm{Ca}^{2+}\right]_{i}$ by $6-\mathrm{OHDA}$ was completely inhibited by NAC, an antioxidant (Figure 4). These results imply that there is a cause-and-effect relationship between ROS and $\left[\mathrm{Ca}^{2+}\right]_{i}$ in terms of the mediation of $6-\mathrm{OHDA}$ toxicity in SK-N-SH cells, and that $\left[\mathrm{Ca}^{2+}\right]_{i}$ may be downstream of ROS induction by 6-OHDA.

Redox stress and $\left[\mathrm{Ca}^{2+}\right]$ increase can lead to mitochondrial $\mathrm{Ca}^{2+}$ overload and the mitochondrial permeability transition (MPT) (Armstrong, 2006). The MPT, in turn, results in matrix expansion and mechanical rupture of the outer membrane allowing the release of apoptogenic proteins, including cytochrome $c$, from the mitochondrial inter-membrane space to the cytosol (Petit et al., 1996, 1998; Skulachev, 1996). In this process, Bcl-2 family proteins play a key regulatory role (Kluck et al., 1997; Yang et al., 1997; Green and Reed, 1998). While the anti-apoptotic protein $\mathrm{Bcl}-2$ blocks mitochondrial cytochrome $\mathrm{c}$ release, the proapoptotic proteins Bax and Bak are believed to form a channel in the outer membrane through which cytochrome $c$ passes into the cytosol (Korsmeyer, 2000). Cytosolic cytochrome $c$ induces cleavage of procaspase 3 to caspase 3 (Auchon et al., 2002; Kwon et al., 2003). Active caspase 3 then mediates the apoptotic cascade. Although there are several reports showing that 6-OHDA toxicity is related to the altered expression of $\mathrm{Bcl}-2$ family proteins (Tsao et al., 2003; Mladenovic et al., 2004), the signaling pathway involved in 6-OHDA-induced $\mathrm{Bcl}-2$ level change and cell death is not fully understood. The results of the present study showed that 6-OHDA induced ROS-dependent $\left[\mathrm{Ca}^{2+}\right]_{i}$ increase (Figure 4B), decreased expression of anti-apoptotic protein $\mathrm{Bcl}-2$ (Figure $5 \mathrm{~A}$ ), and activation of caspase-3 (Figure 6A). Furthermore, the blockade of increased ROS and $\left[\mathrm{Ca}^{2+}\right]_{i}$ by NAC and BAPTA significantly suppressed the 6-OHDA-induced decreased expression of $\mathrm{Bcl}-2$ (Figure 5B) and caspase-3 activation (Figure $6 \mathrm{C}$ ). These results suggest that 6-OHDAinduced neuronal cell death may be mediated by redox stress and mitochondrial apoptotic pathway.

Recently, the contribution of p38 MAPK to 6OHDA-induced cell death and the events upstream and downstream of p38 leading to dopaminergic neuronal death were evaluated (Ouyang and Shen, 2006). Previously others report that 6-OHDA-induced cell death was prevented by p38 inhibitor PD169316 (Choi et al., 2004). In the present study, p38 inhibitor SB203580 also reduced the 6-OHDAinduced cell death. However, the protective effect of SB203580 on 6-OHDA-induced cell death was found to be much lower than that of BAPTA or NAC. Moreover, the inhibition of p38 phosphorylation by SB203580 did not suppress the 6-OHDA-induced increase in ROS, the $\mathrm{Bax} / \mathrm{Bcl}-2$ ratio, or caspase- 3 activity, thus demonstrating that p38 activation is a component of a non-mitochondrial signaling pathway that leads to 6-OHDA-induced cell death, and which acts in concert with an ROS-Ca ${ }^{2+}-\mathrm{Bcl}-2$-caspase-3 pathway. The protective effect of fustin on the 6OHDA-induced phosphorylation of p38 appears to be mediated via the suppression of ROS and $\left[\mathrm{Ca}^{2+}\right]_{i}$ increases since fustin was found to inhibit both; moreover, inhibitors of ROS and $\left[\mathrm{Ca}^{2+}\right]_{i}$ blocked p38 
A

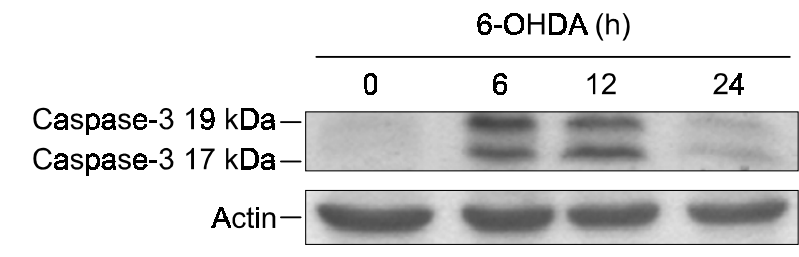

B

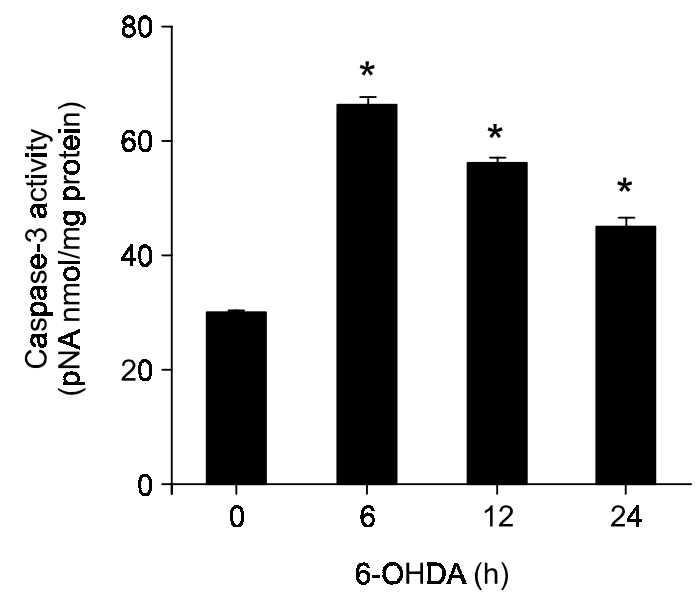

C

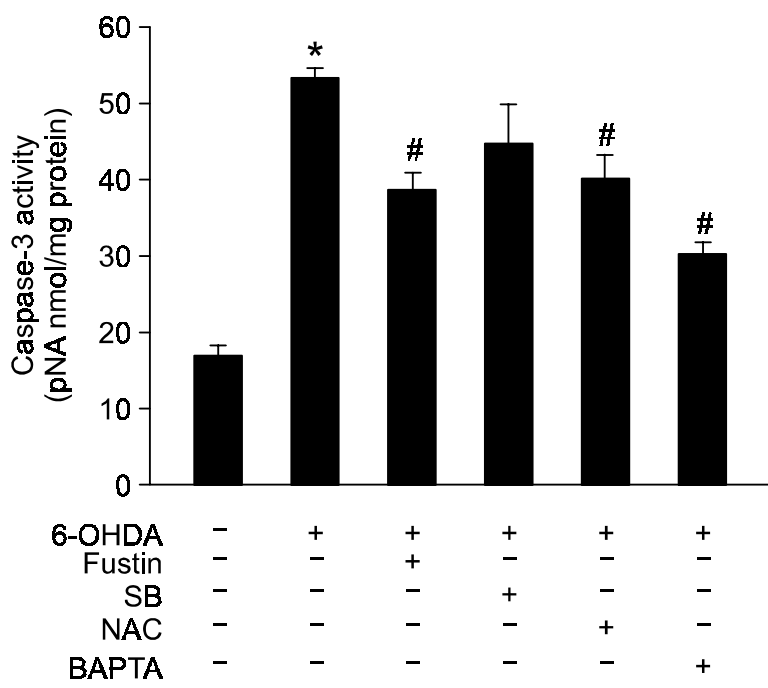

Figure 6. Fustin, NAC and BAPTA inhibit the 6-OHDA-induced activation of caspase-3. (A) Cells exposed to $125 \mu \mathrm{M}$ of 6-OHDA for different times were lysed, and equal amounts of protein were immunoblotted using antibody specific to the caspase-3 cleavage products. (B) Caspase-3 activities were determined using a caspase-3 activity assay kit (BD Biosciences, San Jose, CA). Data represent the mean values of three experiments and bars indicate SEMs. (C) Caspase-3 activity was measured in cells treated with 6-OHDA for $1 \mathrm{~h}$. Fustin $(150 \mu \mathrm{M}), \mathrm{SB} 203580(10 \mu \mathrm{M}), \mathrm{NAC}(1 \mathrm{mM})$ or BAPTA $(2 \mu \mathrm{M})$ were added 30 min prior to 6-OHDA but BAPTA $(2 \mu \mathrm{M})$ was added $4 \mathrm{~h}$ before $6-$ OHDA. Data represent the mean values of three experiments and bars indicate SEMs. ${ }^{*} P<0.05$ compared to the untreated control. ${ }^{\#} P<0.05$ compared with 6 -OHDA alone.

phosphorylation by 6-OHDA.

Based on our results, we propose signaling pathway involved in 6-OHDA-induced cell death and mechanism of fustin on 6-OHDA-activated intracellular signals. 6-OHDA activates two signaling pathways. The major pathway involves ROS and $\left[\mathrm{Ca}^{2+}\right]_{\mathrm{i}}$ mediated increases in the $\mathrm{Bax} / \mathrm{Bcl}-2$ ratio and in caspase- 3 activity, whereas the minor pathway involves p38 activation which does not interact with the mitochondrial (Bax/Bcl-2-caspase-3) signaling pathway. Fustin protects neurons from 6-OHDA-induced cell death by inhibiting both $\mathrm{ROS}-\mathrm{Ca}^{2+}-\mathrm{Bax} / \mathrm{BCl}-$ 2-caspase-3 and ROS-Ca ${ }^{2+}$-p38 pathways.

In conclusion, our results strongly suggest that fustin protects neurons from 6-OHDA-induced death by inhibiting the $\mathrm{ROS}$ and $\mathrm{Ca}^{2+}$ increases induced by OHDA, and thus, their downstream signals. The present study further suggests that fustin is of pharmacologic interest agent for the treatment of PD.

\section{Acknowledgement}

This work was supported by Korea Research Foundation Grant (KRF-2006-005-J01102).

\section{References}

Andrew R, Watson DG, Best SA, Midgley JM, Wenlong H, Petty RK. The determination of hydroxydopamines and other trace amines in the urine of Parkinsonian patients and normal controls. Neurochem Res 1993;18:1175-7

Armstrong JS. The role of the mitochondrial permeability transition in cell death. Mitochondrion 2006;6:225-34

Auchon D, Jiang X, Morgan D, Heuser JE, Wang X, Akey CW. Three-dimensional structure of the apoptosome: implications for assembly, procaspase- 9 binding, and activation. Mol Cell 2002;9:423-32

Bae JH, Park JW, Kwon TK. Ruthenium red, inhibitor of mitochondrial $\mathrm{Ca}^{2+}$ uniporter, inhibits curcumin-induced apoptosis via the prevention of intracellular $\mathrm{Ca}^{2+}$ depletion and cytochrome c release. Biochem. Biophys Res Commun 2003; 303:1073-9 
A

\begin{tabular}{|c|c|c|c|c|c|c|}
\hline & \multirow[b]{2}{*}{0} & \multicolumn{5}{|c|}{ 6-OHDA (h) } \\
\hline & & 0.25 & 0.5 & 1 & 3 & 6 \\
\hline pp38 - & & & & & - & 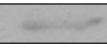 \\
\hline p38- & 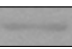 & + & - & - & 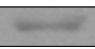 & \\
\hline Actin - & $v$ & 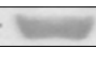 & 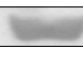 & 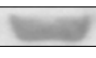 & 4 & 20 \\
\hline
\end{tabular}

\section{B}
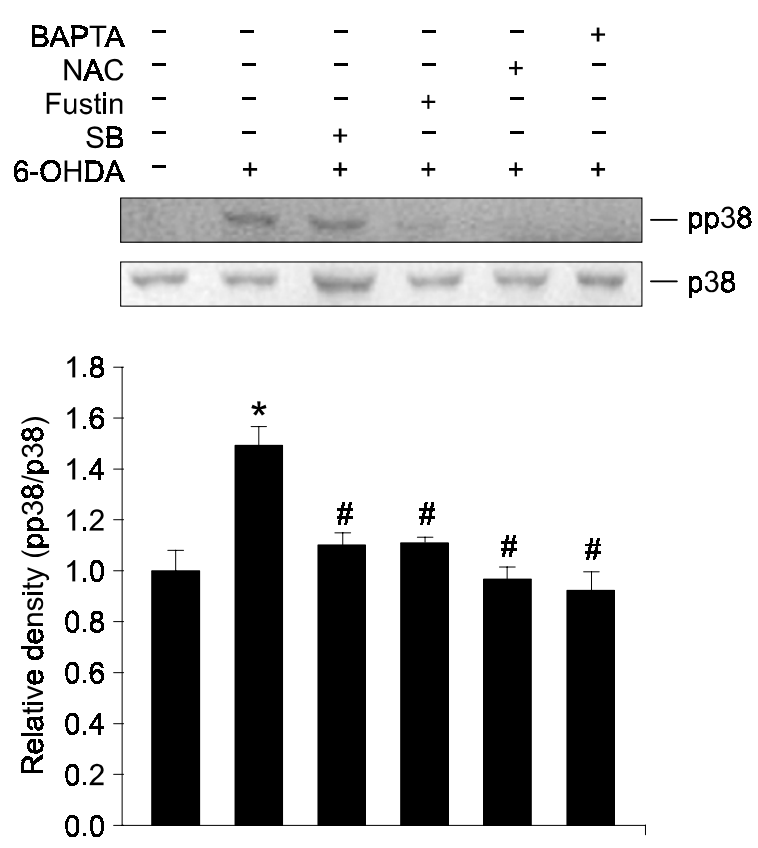

Figure 7. The effects of fustin, NAC and BAPTA on 6-OHDA-induced p38 phosphorylation in SK-N-SH cells. (A) Cells were treated with 6-OHDA for the times shown. (B) Cells were pretreated with SB203580 $(10 \mu \mathrm{M})$, NAC $(1 \mathrm{mM})$ or fustin $(150 \mu \mathrm{M})$ for $30 \mathrm{~min}$, or BAPTA $(2 \mu \mathrm{M})$ for $4 \mathrm{~h}$ prior to 6-OHDA treatment for $6 \mathrm{~h}$. Equal amounts of protein (50 $\mu \mathrm{g})$ were immunoblotted using antibody against the phosphorylated form of p38. Blots were then stripped and reprobed with antibody against total p38. The densities of protein bands were measured and expressed as ratios of phosphorylated versus total p38. The bar graph represents the mean values of three different cultures and bars indicating SEM. ${ }^{*} P<0.05$ compared to the untreated control, ${ }^{\sharp} P<0.05$ compared to treatment with 6-OHDA alone.

Beal MF. Experimental models of Parkinson's disease. Nat Rev Neurosci 2001;2:325-34

Bharath S, Hsu M, Kaur D, Rajagopalan S, Andersen JK. Glutathione, iron and Parkinson's disease. Biochem Pharmacol 2002;64:1037-48

Borner $\mathrm{C}$. The $\mathrm{Bcl}-2$ protein family: sensors and checkpoints for life-or-death decisions. Mol Immunol 2003;39:615-47

Bruce-Keller AJ, Begley JG, Fu W, Butterfield DA, Bredesen DE, Hutchins JB, Hensley K, Mattson MP. Bcl-2 protects iso- lated plasma and mitochondrial membranes against lipid peroxidation induced by hydrogen peroxide and amyloid beta-peptide. J Neurochem 1998;70:31-39

Cassarino DS, Halvorsen EM, Swerdlow RH, Abramova NN, Parker WD, Jr Sturgill TW, Bennett JP. Jr Interaction among mitochondria, mitogen-activated protein kinases, and nuclear factor-kappaB in cellular models of Parkinson's disease. J Neurochem 2000;74:1384-92

Choi J, Yoon BJ, Han YN, Lee KT, Ha J, Jung HJ, Park HJ. Antirheumatoid arthritis effect of Rhus verniciflua and of the active component, sulfuretin. Planta Med 2003;69:899-904

Choi WS, Yoon SY, Oh TH, Choi EJ, O'Malley KL, Oh YJ. Two distinct mechanisms are involved in 6-hydroxydopamine- and MPP+-induced dopaminergic neuronal cell death: role of caspases, ROS, and JNK. J Neurosci Res 1999;57:86-94

Choi WS, Eom DS, Han BS, Kim WK, Han BH, Choi EJ, Oh TH, Markelonis G J, Cho JW, Oh YJ. Phosphorylation of p38 MAPK induced by oxidative stress is linked to activation of both caspase-8- and -9-mediated apoptotic pathways in dopaminergic neurons. J Biol Chem 2004;279:20451-60

Chun HS, Gibson G.E, DeGiorgio LA, Zhang H, Kidd VJ, Son $\mathrm{JH}$. Dopaminergic cell death induced by MPP $(+)$, oxidant and specific neurotoxicants shares the common molecular mechanism. J Neurochem 2001;76:1010-21

Cohen G, Farooqui R, Kesler N. Parkinson disease: a new link between monoamine oxidase and mitochondrial electron flow. Proc Natl Acad Sci U S A 1997;94:4890-4894

Curtius HC, Wolfensberger M, Steinmann B, Redweik U, Siegfried J. Mass fragmentography of dopamine and 6hydroxydopamine. Application to the determination of dopamine in human brain biopsies from the caudate nucleus. J Chromatography 1974;99:529-40

Danielczyk W, Streifler M, Konradi C, Riederer P, Moll G.. Platelet MAO-B activity and the psychopathology of Parkinson's disease, senile dementia and multi-infarct dementia. Acta Psychiatr Scand 1998;78:730-6

Dauer W, Przedborski S. Parkinson's disease: mechanisms and models. Neuron 2003;39:889-909

Dawson TM, Dawson VL. Molecular pathways of neurodegeneration in Parkinson's disease. Science 2003;302: 819-22

Di Virgilio F, Fasolato C, Steinberg TH. Inhibitors of membrane transport system for organic anions block fura-2 excretion from PC12 and N2A cells. J Biol Chem 1998;256:959-63

Ferrer I, Blanco R, Carmona M, Puig B, Barrachina M, Gomez $C$, Ambrosio S. Active, phosphorylation-dependent mitogenactivated protein kinase (MAPK/ERK), stress-activated protein kinase/c-Jun N-terminal kinase (SAPK/JNK), and p38 kinase expression in Parkinson's disease and Dementia with Lewy bodies. J Neural Transm 2001;108:1383-96

Floor E, Wetzel MG. Increased protein oxidation in human substantia nigra pars compacta in comparison with basal ganglia and prefrontal cortex measured with an improved dinitrophenylhydrazine assay. J Neurochem 1998;70:268-75

Froissard P, Monrocq H, Duval D. Role of glutathione metabo- 
lism in the glutamate-induced programmed cell death of neuronal-like PC12 cells. Eur J Pharmacol 1997;326:93-9

Glinka Y, Gassen M, Youdim MB. Mechanism of 6-hydroxydopamine neurotoxicity. J Neural Transm 1997;50(Suppl): $55-66$

Glinka YY, Youdim MB. Inhibition of mitochondrial complexes I and IV by 6-hydroxydopamine. European Journal of Pharmacology 1995;292:329-32

Green DR, Reed JC. Mitochondria and apoptosis. Science 1998;281:1309-12

Gross A, Yin XM, Wang K, Wei MC, Jockel J, Milliman C, Erdjument-Bromage $\mathrm{H}$, Tempst $\mathrm{P}$, Korsmeyer SJ. Caspase cleaved BID targets mitochondria and is required for cytochrome $\mathrm{c}$ release, while $\mathrm{BCL}-\mathrm{XL}$ prevents this release but not tumor necrosis factor-R1/Fas death. J Biol Chem 1999;274: 1156-63

Hattori N, Tanaka M, Ozawa T, Mizuno Y. Immunohistochemical studies on complexes I, II, III, and IV of mitochondria in Parkinson's disease. Ann Neurol 1991;30:563-71

Hochman A, Sternin H, Gorodin S, Korsmeyer S, Ziv I, Melamed E, Offen D. Enhanced oxidative stress and altered antioxidants in brains of Bcl-2-deficient mice. J Neurochem 1998;71:741-8

Hockenbery D, Nunez G, Milliman C, Schreiber RD, Korsmeyer SJ. Bcl-2 is an inner mitochondrial membrane protein that blocks programmed cell death. Nature 1990;348:334-6

Jambrina E, Alonso R, Alcalde M, Rodriguez MC, Serrano A, Martinez AC, Garcia-Sancho J, Izquierdo M. Calcium influx through receptor-operated channel induces mitochondriatriggered paraptotic cell death. J Biol Chem 2003;278: 14134-45

Kim JA, Kang YS, Kim YO, Lee SH, Lee YS. Role of $\mathrm{Ca}^{2+}$ influx in the tert-butyl hydroperoxide-induced apoptosis of HepG2 human hepatoblastoma cells. Exp Mol Med 1998; 30:137-44.

Kluck RM, Bossy-Wetzel E, Green DR, Newmeyer DD. The release of cytochrome $c$ from mitochondria: a primary site for $\mathrm{Bcl}-2$ regulation of apoptosis. Science 1997;275:1132-6

Korsmeyer SJ, Wei MC, Saito M, Weiler S, Oh KJ, Schlesinger $\mathrm{PH}$. Pro-apoptotic cascade activates BID, which oligomerizes BAK or BAX into pores that result in the release of cytochrome c. Cell Death Differ 2000;7:1166-73

Kumar R, Agarwal AK, Seth PK. Free radical-generated neurotoxicity of 6-hydroxydopamine. J Neurochem 1995;64:1703-7

Kwon KB, Kim EK, Shin BC, Seo EA, Yang JY, Ryu DG. Herba houttuyniae extract induces apoptotic death of human promyelocytic leukemia cells via caspase activation accompanied by dissipation of mitochondrial membrane potential and cytochrome c release. Exp Mol Med 2003;35:91-7.

Lee WT, Yin HS, Shen YZ. The mechanisms of neuronal death produced by mitochondrial toxin 3-nitropropionic acid: the roles of $\mathrm{N}$-methyl-D-aspartate glutamate receptors and mitochondrial calcium overload. Neuroscience 2002;112:707-16

Lotharius J, Dugan LL, O'Malley KL. Distinct mechanisms underlie neurotoxin-mediated cell death in cultured dopaminergic neurons. J Neurosci 1999;19:1284-93
Lotharius JO, Malley KL. The parkinsonism-inducing drug 1-methyl-4-phenylpyridinium triggers intracellular dopamine oxidation. A novel mechanism of toxicity. J Biol Chem 2000; 275:38581-8

Mielke K, Herdegen T. JNK and p38 stress kinases-degenerative effectors of signal-transduction-cascades in the nervous system. Prog Neurobiol 2000;61:45-60

Mladenovic A, Perovic M, Raicevic N, Kanazir S, Rakic L, Ruzdijic S. 6-Hydroxydopamine increases the level of TNFalpha and bax mRNA in the striatum and induces apoptosis of dopaminergic neurons in hemiparkinsonian rats. Brain Res 2004; $996: 237-45$

Ogawa N, Asanuma MK, Kondo Y, Nishibayashi S, Mori A. Reduced choline acetyltransferase activity and muscarinic M1 receptor levels in aged Fisher 344 rat brains did not parallel their respective mRNA levels. Brain Res 1994;658:87-92

Ouyang M, Shen X. Critical role of ASK1 in the 6-hydroxydopamine-induced apoptosis in human neuroblastoma SH-SY5Y cells. J Neurochem 2006;97:234-44

Park KY, Jung GO, Lee KT, Choi J, Choi MY, Kim GT, Jung HJ, Park HJ. Antimutagenic activity of flavonoids from the heartwood of Rhus verniciflua. J Ethnopharmacol 2004; 90:73-9

Petit PX, Susin SA, Zamzami N, Mignotte B, Kroemer G. Mitochondria and programmed cell death: back to the future. FEBS Lett 1996;396:7-13

Petit PX, Goubern M, Diolez P, Susin SA, Zamzami N, Kroemer G. Disruption of the outer mitochondrial membrane as a result of large amplitude swelling: the impact of irreversible permeability transition. FEBS Lett 1998;426:111-6

Przedborski S, Levivier M, Jiang H, Ferreira M, Jackson-Lewis $V$, Donaldson D, Togasaki DM. Dose-dependent lesions of the dopaminergic nigrostriatal pathway induced by intrastriatal injection of 6-hydroxydopamine. Neuroscience 1995;67:31-64

Reichman N, Porteous CM, Murphy MP. Cyclosporin A blocks 6-hydroxydopamine-induced efflux of $\mathrm{Ca}^{2+}$ from mitochondria without inactivating the mitochondrial inner-membrane pore. Biochem J 1994;297:151-5

Reynolds IJ. Mitochondrial membrane potential and the permeability transition in excitotoxicity. Ann NY Acad Sci 1999; 893:33-41

Richter C, Frei B. $\mathrm{Ca}^{2+}$ release from mitochondria induced by prooxidants. Free Radic. Biol Med 1988;4:365-75

Saporito MS, Brown EM, Miller MS, Carswell S. CEP1347/KT-7515, an inhibitor of c-jun N-terminal kinase activation, attenuates the 1-methyl-4-phenyl tetrahydropyridinemediated loss of nigrostriatal dopaminergic neurons in vivo. J Pharmacol Exp Ther 1999;288:421-7

Saporito MS, Thomas BA, Scott RW. MPTP activates c-Jun $\mathrm{NH}(2)$-terminal kinase (JNK) and its upstream regulatory kinase MKK4 in nigrostriatal neurons in vivo. J Neurochem 2000;75:1200-8

Sauer $\mathrm{H}$, Oertel WH. Progressive degeneration of nigrostriatal dopamine neurons following intrastriatal terminal lesions with 6-hydroxydopamine: a combined retrograde tracing and im- 
munocytochemical study in the rat. Neuroscience 1994;59: 401-15

Seitz H, Stinner D, Eikmann T, Herr C, Roosli M. Electromagnetic hypersensitivity (EHS) and subjective health complaints associated with electromagnetic fields of mobile phone communication--a literature review published between 2000 and 2004. Sci Total Environ 2005;349:45-55

Sherer TB, Betarbet R, Stout AK, Lund S, Baptista M, Panov AV, Cookson MR, Greenamyre JT. An in vitro model of Parkinson's disease: linking mitochondrial impairment to altered alpha-synuclein metabolism and oxidative damage. $\mathrm{J}$ Neurosci 2002;22:7006-15

Shimizu E, Hashimoto K, Komatsu N, lyo M. Roles of endogenous glutathione levels on 6-hydroxydopamine-induced apoptotic neuronal cell death in human neuroblastoma SK-N-SH cells. Neuropharmacol 2002;43:434-43

Skulachev VP. Why are mitochondria involved in apoptosis? Permeability transition pores and apoptosis as selective mechanisms to eliminate superoxide-producing mitochondria and cell. FEBS Lett 1996;397:7-10

Soto-Otero R, Mendez-Alvarez E, Hermida-Ameijeiras A, Munoz-Patino AM, Labandeira-Garcia JL. Autoxidation and neurotoxicity of 6-hydroxydopamine in the presence of some antioxidants: potential implication in relation to the pathogenesis of Parkinson's disease. J Neurochem 2000;74: 1605-12

Tatton NA. Increased caspase 3 and Bax immunoreactivity accompany nuclear GAPDH translocation and neuronal apoptosis in Parkinson's disease. Exp Neurol 2000;166:29-43

Tsao CW, Cheng JT, Lin YS. Down-regulation of Bcl-2, activation of caspases, and involvement of reactive oxygen species in 6-hydroxydopamine-induced thymocyte apoptosis. Neuroimmunomodulation 2002-2003;10:328-36

Vroegop SM, Decker DE, Buxser SE. Localization of damage induced by reactive oxygen species in cultured cells. Free Radic Biol Med 1995;18:141-51

Xia Z, Dickens M, Raingeaud J, Davis RJ, Greenberg ME. Opposing effects of ERK and JNK-p38 MAP kinases on apoptosis. Science 1995;270:1326-31

Yang J, Liu X, Bhalla K, Kim CN, Ibrado AM, Cai J, Peng TI, Jones DP, Wang X. Prevention of apoptosis by Bcl-2: release of cytochrome c from mitochondria blocked. Science 1997; 275:1129-32 